Pakistan Journal of Humanities and Social Sciences

July - December 2017, Volume 5, No. 2, Pages 124 - 139

\title{
Elite Pakistan Press Discourse on US Drone Policy
}

\author{
Akber $A l i^{1}$ \\ ${ }^{1}$ PhD Scholar, Shanghai Film Academy, Shanghai University, China, Faculty, Karakoram \\ International University, Gilgit- Baltistan, Pakistan \\ Email: akber.ali@kiu.edu.pk
}

\begin{abstract}
Scholars in the arena of media and communication have paid attention to the news framing of the controversial US drone policy in the post 9/11 mainly from the Western media perspectives. Scant scholarly heed has been given to examine the media framing of the US drone strikes from the national media perspectives of the targeted countries. The current study attempts to build on the existing scholarship on US drone policy by exploring the news media framing in two elite national newspapers of Pakistan. Using inductive framing as methodological approach and qualitative analysis as methodology, the study analyzed the editorial discourse in the selected dailies on the US drones. The findings reveal that both the newspapers covered the drones using strikingly different frames. The Daily Times constructed the discourse on US drones using the efficacy frame predominantly- that the drones are effective and doing 'good job' against the militants. The Express Tribune framed the drones as violation of Pakistan's sovereignty and counterproductive. The discussion elaborates the possible factors for the differential framing of US drones in the two national dailies of Pakistan.
\end{abstract}

Keywords: US drones, framing theory, inductive framing, Pakistani press, qualitative analysis

\section{Introduction}

In the post 9/11, the Unites States has launched controversial drone strikes as a centre piece of counterterrorism policy in a number of countries of Asia and Africa including Pakistan, Yemen, Afghanistan, Somalia and Iraq. This security policy of the US has been fiercely debated globally among the public, legal experts, UN and in the official circles of the targeted countries with competing narratives over the legality, morality and technological precision. The US defends the drone policy as legal and effective with minimum collateral damage. The former Central Intelligence Director (CIA), defended the drones tellingly, 'the only game in town in terms of confronting or trying to disrupt the Al Qaeda leadership' (CNN, 2009). President Obama while speaking at the National Defense University termed the 
Pakistan Journal of Humanities and Social Sciences, 5(2), 2017

drones strikes as a 'just war- a war waged proportionally, in last resort, and in self-defense (New York Times, May 23, 2013). Likewise, polls have shown that 58\% of the public surveyed in the US supported the US drones in Pakistan and elsewhere (Pew Research Centre, 2015). The UN Special Rapporteur on Human Rights Ben Emmerson in 2013 asserted that the drone strikes in Pakistan are illegal and confirmed the civilian causalities (The Guardian, 2013).

In Pakistan, the drones have remained a controversial issue and perhaps the biggest cause of contentious relationship between the two countries where since 2004, reportedly 363 drone strikes have been conducted in killing between 2445 and 3945 individuals including between 421 to 960 civilians (Bachman, 2015). Former Army Chief, General Raheel Sharif had termed the drones as regrettable as they are a "threat to the sovereignty and security of the country" (Haider, 2016). In a similar vein, the former President Asif Zardari during his meeting to the David H. Petraue-the head of the US Central Command complained about the drone strikes in Pakistan and said, "Continuing drone attacks on our territory, which result in loss of precious lives and property, are counterproductive and difficult to explain by a democratically elected government. It is creating a credibility gap" (New York Times, 2008). In June 2013, the National Assembly of Pakistan passed a unanimous resolution against the US drone strikes calling them as violation of UN Charter and International law and humanitarian norms (Dawn, 2013). Polls have shown that $67 \%$ of the respondents in Pakistan consider the drone attack "kill too many innocent people" and are conducted without the approval of Pakistani government (Pew Research Centre, 2014). However, these poll opinions have been challenged by many studies for their being skewed and reflecting the opinions of the urban people who are not under the direct threat of the US drones and do not reflect the public opinions of the area where drones are fired. Studies conducted in the FATA (Federally Administered Tribal Areas) region have shown the support to the drone strikes from the local community as an effective tool against the militants who have terrorized the Pashtun society and that the drones are better than the ground operations (Williams, 2010; Shah, 2016). As Taj (2010) while rejecting the reports on the civilian killings and unpopularity of the drones in FATA have asserted that the drones are popular in the region where they are fired and that the reports about large scale civilian causalities are untruthful accounts.

Given these fragmented opinions about US drones in Pakistan, we turned our attention to the news media discourses in Pakistan where the drones have been widely reported yet less examined scholarly. We were interested to study how the press in Pakistan 
constructs narratives surrounding the drones. As scholar have noted that the press has significant role in framing and reporting different international events and that the public is stated to be dependent on media for information on internal and external issues (Rasul et al., 2015) .With this backdrop in mind we selected two major elite English dailies of Pakistan namely Daily Times and The Express Tribune in order to examine the discourse and framing of the US drones in the elite press of Pakistan. This article proceeds first by briefly elucidating the existing literature on news media and drones.

\section{Literature Review}

Despite a fiercely debated topic in various realms, no substantive scholarly attention has been paid to understand how the news media of the targeted countries build narratives about the drone strikes. Few comparative studies have been conducted in cross political and cultural settings on drones with interesting findings. In a comparative study of US, UK and Arabic media framing of drones, Sheets, Rowling and Jones (2015) have revealed the US news media framed drone usage favorably by emphasizing it legality, strategic value and the technological sophistication while de-emphasizing and underreporting the civilian deaths caused by the drones. The Arabic and the British media coverage were more critical and emphasized on the collateral damage by the drone strikes. Ottosen (2014) in a comparative analysis of the legal aspects of the drone strikes in the New York Times and the Norwegian newspaper Aftenposten have concluded that both the newspapers were uncritical in their coverage vis-à-vis the legal aspects of drone strikes. In a similar study, Bachman (2015) has revealed that the New York Times and Washington Post misled the public about the US drones in their news coverage by misreporting the civilian deaths caused by the drones in Pakistan and Yemen. Both the elite newspapers failed to mention the legal aspects and the collateral damage in their reporting on the US drones and thus uncritically accepted the US official narratives.

Studies on counterterrorism have revealed that the new media framing of counterterrorism is not homogenous across the national and ideological settings. National interests, ideological positions of states, attitudes of one state towards another and social identity of the journalists among other factors could be possible explanations for the differential framing of news issues across the national frontiers. For instance the killing of Osama Bin Laden as a counterterrorism act was a great breakthrough for many countries, nations and media. Yet the same issue was framed variedly in various cultural and political contexts. In a comparative media framing study of the killing of Osama Bin Laden in the US 
and Russian media, Storie, Madden and Liu (2014) have concluded that terrorism events are framed as a national concern rather than a global issue. The US and Russian media used different frames and narrative on the killing of Osama Bin Laden. The US media framed it as a great breakthrough in the war on terror and a great victory for the US; the Russian media on the other hand frame the killing in much ambivalent terms and used the secrecy and humanizing frames showing much cynicism toward the US actions of counterterrorism. Other studies have shown that the US press reported favorably the US drones strikes in Pakistan framing them as an effective strategy against the war on terror and saving the American lives (Jones, Sheets \& Rowling, 2011). What lacks in the existing literature on drones is an inside view i.e. how the news media of the targeted countries frame the drone policy. The current study thus aims to fulfill this gap and to build on the existing scholarship of news media and counterterrorism by exploring framing of the US drones in the elite English press of Pakistan because Pakistan has received the highest number of drone strikes (Bergen \& Tiedemann, 2010) yet the press coverage of these drones have not been explored yet. Thus the study attempts to explore the following questions:

- How did the Daily Times frame the US drone issues in Pakistan?

- How did The Express Tribune frame the drones?

- Are there similarities and differences in the framing of the drones in the elite press?

\section{Theoretical Approach}

\section{A. News Framing Theory}

The mass media play a central role in the construction of meaning about the events and issues of the social world. A theoretical lens that has been widely used to understand how the news media report certain aspects of a reality while excluding others is the framing theory. News frames are "conceptual tools which media and individuals rely on to convey, interpret, and evaluate information" (Neuman et al., 1992, p.60). Broadly speaking news framing refers to the ways in which mass media organize and present issues for the audiences. News is a social construction of reality about issues and events and not an objective account (Shoemaker \& Reese, 1996, p.121). Journalists use the news frame to simplify and structure the narrative flow of events about the social world (Norris, 1995, p.358). Lewis and Reese (2009) have discussed that frames are tools used by the social actors to structure reality and are "often embedded in and resonate with the everyday culture, and thus are considered normal and natural, their impact is by stealth" (p.3). 
Chong and Druckman (2007) have defined framing as a theory that refers to the process of conceptualization of an issue by the public or reorientation of the public thinking about an issue. Other scholars have noted that framing essentially involves salience and selection. Entman (1991, p. 7) notes that "news frames are constructed from and embodied in the key words, metaphors, concepts, symbols and visual images emphasized in a news narrative". Gitlin (1980) who is often credited to introduce the framing concept in the news media notes, 'media frames, largely unspoken and unacknowledged organize the world both for journalists who report it and, in some important degree, for us who rely on their reports' (p.7). Norris (1995, p.358) notes news frame as "an interpretative structure that sets particular events within a broader context". A widely cited concept about framing has been given by Entman (1993) which states,

To frame is to select some aspects of a perceived reality and make them more salient in a communicating text, in such a way as to promote a particular problem definition, causal interpretation, moral evaluation, and/or treatment recommendation for the item described. (p.52)

Other scholars have defined frames as "interpretive package" that prioritizes a certain explanation or significance of an event (Gamson and Modigliani, 1989). Framing could limit the public understanding of issues by presenting a limited interpretation of issues and thus promoting a particular problem definition and casual interpretations. Iyengar (1990) has noted that the news media framing of an issue could be either episodic or thematic. Episodic frames are issue and event specific without providing any broader context and the thematic frames on the other hand discuss issues and events in a more broader and historical context. Thus a drone strike could be presented as an isolated and specific event presenting the killings of the militants; thematic framing on the other hand will discuss the drone strikes in a broader legal, moral and humanitarian context. Such framing has implications for the public understanding and causal responsibility of issues and in deciding how people think and talk about public issues. For example when news stories cover public issues with a thematic frame, readers attribute responsibility to the society than to the individuals (Iyengar, 1990).

While scholars have noted the conceptual inconsistency of framing tradition and its application (Entman, 1993) framing theory is still widely used in the media research to examine the role of the news media in constructing meanings about international issues and their influence on the public interpretation of the issues (Rasul et al., 2015) to make a mental map about the world (Zhu \& Lu, 2013). Newspapers were selected because they are still considered to be the basic sources of information for audience especially during the crises 
Pakistan Journal of Humanities and Social Sciences, 5(2), 2017

situations to read the news in more details are argued to be important sites for articulating nationalism and national agendas (Li, 2009; Billig, 1995). In Pakistan, the print press has a long cherished tradition of independence and professional autonomy. The print media is considered a source of media independence for the newly liberalized electronic media (Nadadur, 2007). Thus keeping in view their significance national dailies were made part of the current study.

\section{Method}

This study employed an inductive framing analysis to explore the news media framing of US drones in Daily Times and The Express Tribune. Inductive framing is one of the two approaches used in frame analysis which is employed to analyze news stories without predefining news frames or categories and attempts to reveal an array of possible frames with loosely defined preconceptions of these frames (Semetko \& Valkenburg, 2000, p. 94). Inductive framing is useful in discerning implicit recurring themes and provides meaningful insights into the interpretative frames used in the news discourse (e.g. Golan \& Lukito, 2015) and is pertinent when a phenomenon is new and the sample size is small. The limitation of inductive approach is the replication. Previous studies have noted the significance of inductive framing analysis in exploring a phenomenon which scholars have not explored previously and using which could unravel the themes and frames embedded in the media texts on crucial national and international issues ( See Golan, Lukito, 2015, Reese \& Lewis, 2009; Golan \& Carroll, 2012; de Souza, 2010).

Two elite national newspapers, Daily Times and The Express Tribune were selected for the study. Both the newspapers are major English dailies belonging to the major media groups in Pakistan. Daily Times is a leading popular major English daily (Nadadur, 2007; Romero-Trillo, 2011) and is considered to be one of the elite English newspapers of Pakistan with a comparatively small circulation yet is argued to have influence over the opinion shaping of the elites of society (Alasuutari, Qadir \& Creutz, 2013) with a liberal orientation and rigorous readership and acts as a major source of foreign and domestic news as compared to the other smaller national dailies (Qadir \& Alasuutari, 2013). The Express Tribune is relatively a new entrant in the limited English media landscape of Pakistan and is one of the widely circulated elite newspapers. All the editorials published on drones in the selected dailies during 2013 to 2016 were selected from the online archives of the newspapers for free. This time period is important as during the Obama administration the highest number of drones strikes occurred in Pakistan and the media had given wide scale coverage. The unit of 
analysis was the individual editorial. Only the editorials that directly discussed the drones in Pakistan were made part of the analysis.

The rationale for selecting editorials lies in the fact that editorials are important news genres that reflect the ideological stance of the news media organizations (Izadi \& SaghayeBiria, 2007) and offer an important site to study the ideological positions of news on major political issues (Lee et al., 2011) and are noted to be less constrained by the professional conventions of objectivity and neutrality (Lee \& Lin, 2006). Given the accessibility issue to the FATA region for the journalists (Taj, 2010), news stories about the drones were mainly taken from the military official and international news agencies that might not reflect the Pakistani media stances on US drones although media tend to 'domesticate' international news stories to render them into the local realities (Gurevitch et al., 1991 as cited in Qadir \& Alasuutari, 2013, p. 575). Thus selecting and analyzing the editorial discourse seems to be a pertinent choice to reveal the organizational stances of the newspapers on salient national and international issues.

\section{Findings and Analysis}

Using the qualitative framing analysis approach, we read the editorials multiple times to identify the frames used to construct the discourse and an overall sense of the news text. We paid special attention to key words, metaphors, catchphrases and the exemplars the newspapers used to construct the discourse on the topic and the recurring themes and patterns which appeared repeatedly. As a rule of qualitative framing analysis, notes were taken by reading each sentence and paragraph multiple times to answer the question that how the drones are being talked about in the editorial discourse. Besides, attention was also given to the overall valence of each editorial for positive or negative tone and the different frames the newspapers have used to cover the drone issue. Our iterative, back and forth reading, and constant comparison method (Strauss \& Corbin, 1990) revealed meaningful differences in the framing of the drones in Daily Times and The Express Tribune. The Express Tribune framed the US drone strikes as sovereignty violation and counterproductive with an overall negative tone towards the US actions. In contrast, Daily Times framed the drones as effective in killing the 'bad guys' with an overall positive tone about the drone strikes. These frames and the surrounding discourses are further analyzed below.

\section{A. The Express Tribune: Drones as sovereignty violation and counterproductive}

In the editorial discourse on US drones, The Express Tribune repeatedly echoed the violation of sovereignty by the US drones and demanded that if the US did not listen to the 
concerns of Pakistan, the drones be shoot down by the Pakistan jets. It frequently argued that in the presence of Pakistani jests operating in the tribal areas there is no justification for the US drones to fly over 'our skies'. The newspaper was critical towards the government in its failure to shoot down the drones and the tacit support of Pakistani government for the US drones despite its opposition in the public posturing. Using the legal and moral reasoning as framing devices, the newspaper constructed the discourse that allowing the US drones will be against the international law and would set precedence to any country to violate the sovereignty of Pakistan. It asserted that without the permission of sovereign state, no country or its actors can enter the space of other countries. As the following excerpts illustrate:

with our own armed forces operating against terrorists groups along the border regions and doing so with sufficient success ... why are American drones still over Pakistan? ..there was apparently no attempt to shoot the $R P V$ [remotely piloted vehicle] that was in violation of our airspace..the implication as ever is that there is a tacit agreement between Pakistan and the US that American drones can operate at will (The Express Tribune, May 24, 2015).

These attacks which have suddenly increased since December 16, 2014, are decidedly illegal, immoral and they undermine the country's sovereignty...if we endorse these attacks because they kill our enemies we would only be according a legal status in international law...to the US or any other country the right to undermine our sovereignty (The Express Tribune, February, 1, 2015).

This framing package is build by using legal, moral and sovereignty lenses to build the narrative that entering and attacking a sovereignty country is illegal both morally and from perspective of international law without the consent of the respective countries. The discourse further elaborated that that the drones are counterproductive as they further fuel extremism, terrorism and anti-Americanism in Pakistan. Reinforcing the government stance at the UN, the newspaper echoed consistently that the drones are counterproductive and have blow effect on Pakistani society as they kill innocent people and cause further extremism and resentment among the Pakistani masses and are 'detrimental to efforts to eliminate extremism and terrorism (The Express Tribune, July 11, 2016). Rejecting the US drone reports on the collateral damage the newspaper mentioned that the report is eyewash from the US administration as the number of civilian deaths is incorrect. It further used the independent reports to counter the US administration reports on the civilian killings in order to frame the drones as counterproductive causing the innocent deaths. As the following example depicts: 
Civilians are killed in these strikes; sometimes the people who are the targets of the strikes knowingly use relatives as human shields. At other times civilians die because they are in wrong place at the wrong time (The Express Tribune, July $3^{\text {rd }}$, 2016).

The newspaper was critical towards the lack of transparency surrounding the US drones and the secret deals between military officials of US and Pakistan and sidelining the civilian leadership of Pakistan. It stressed to bring more transparency regarding the USPakistan ties and to take on board the civilian government of Pakistan on serious security issues like drones and the overall war on terror. As the following excerpt elucidate:

Drones have always been in the shadows, but the time may be right for a little light to be shed and for the government to bring some clarity to an otherwise opaque issue. (May 24, 2015).

CIA continues to send in its armed drones with tacit permission from our premier intelligence agencies, our civilian administrations are morally and ethically free to continue to condemn the attacks (The Express Tribune, July 11, 2016).

A careful examination of the editorial discourse of The Express Tribune reveals that the newspaper strongly opposed the US drones terming it a sovereignty violation and counterproductive. The overall stance of the editorial was highly negative towards the US actions. The newspaper applied thematic framing as outlined by Iyengar (1990) as it discussed the drone issue in a broader context by situating it in the broader frameworks of legal, moral and Pak-US relationship. As the analysis revealed the overarching themes, and recurring patterns were about the sovereignty violation which were repeatedly echoed in the editorial discourse of The Express Tribune to build a narrative that gives highly negative depiction of the US drone strikes using highly emotive language like 'drone wars', ' lethal drones', ' and, ' drone warfare'. As an independent newspaper it remained critical towards the Pakistanis officials both civilians and military and posited to bring transparency about the US-Pakistan ties and to public the alleged tacit agreements vis-à-vis drones strikes in Pakistan.

The newspaper frequently used the collective nouns as 'our drones', 'our sovereignty, 'our spaces' to construct a nationalistic discourse on drones as scholars have noted that the newspaper articles referring to 'we' and 'us' can be understood as referring to the nation and national identity (Wodak, De Cillia, Reisigl, Liebhart, 2009). As findings suggest the editorial discourse of The Express Tribune tends to be more nationalistic and ethnocentric in the sense that it consistently echoed the national sovereignty and identity with predominantly negative 
Pakistan Journal of Humanities and Social Sciences, 5(2), 2017

tone towards the US drone strikes in Pakistan. Additionally, using the latent framing techniques, it depicted highly negative image of the US in the region of Pakistan and Afghanistan. It failed to mention that the drones are part of the war on terror of which Pakistan itself is an ally.

\section{B. Daily Times: Drones as antidote to terrorists}

In contrast to The Express Tribune, Daily Times frame the US drone as antidote - that drones are the best strategy to eliminate the 'murderers'. It repeatedly asserted that the drone strikes are effective response to the terrorists who have killed thousands of innocent people in Pakistan and that any sort of dialogue and peace with the terrorists would be playing in the hands of the 'killers'. It urged the Pakistani government that asking the US to halt the drones in the FATA (Federally Administered Tribal Areas) would embolden the militants thus unproductive for the cause against the war on terror. In a number of editorials the newspaper rejected the rhetoric of the civilian killings as a propaganda by the Taliban apologists and argued that the drones have been precise in targeting the militants and acting as 'deathblow' (March 14, 2014) to terrorism in Pakistan. As the following excerpt narrates:

Drones have time and again been proved the most precise and reliable way to counter the Taliban (Daily Times, March 14, 2014).

The drone strikes by the US were the only thorn in their side [Taliban] because they have been precise and on the mark in taking out their high value Taliban and Al-Qaeda targets (Daily Times, February 8, 2014)

The drone strikes by the US were the only thorn in their side [terrorists] because they have been precise and on the mark in taking out their high value Taliban and al-Qaeda targets....we have provided the militants with the perfect opportunity [ peace talks] to reconsolidate themselves. We are playing into terrorist hands and seem to have duped the US into doing so too (Daily Times, February 8, 2014)

Consistently, the editorial discourse invokes a support for the US drones terming the US as 'our ally' and the drones are helping Pakistani forces to root out the militants from Pakistan. It asserted if Pakistan is operating against the terrorist in the tribal areas, getting assistance from the US in the shape of drone strikes in combating the threat posed by militants is logical (Editorial, Oct 10, 2014). Citing the people of FATA the editorial discourse framed the drone strikes as effective and result oriented and 'our best bet in defeating the terrorist' (March 14, 2014). In one such typical editorial, the paper asserted that:

... no much is said about the people living in the tribal areas, people who have gone on record to as saying that they actually prefer the drones to no action. ... we need to understand that without drones our militant 
problem might get even worse than it already is. It is a mess there and if someone is willing to clean it up, we should welcome it (Daily Times, December 22, 2013).

In a hard hitting editorial the daily criticized the Pakistani government for its repeated rhetoric of the 'sovereignty violation' and called it a double standard to criticize only the US drones for the sovereignty violation of Pakistan and not to talk about the infiltration of the terrorists who have equally violated Pakistani sovereignty by establishing their hideouts in the tribal areas of Pakistan. As the following excerpt shows:

the government [ Pakistan] has been harking on about how the drones are in violation of Pakistan's sovereignty- the double standards are mindboggling, our sovereignty was compromised the moments we allowed foreign fighters to use our soil to launch attacks in Afghanistan and our own citizens. ..we must have the courage to call spade a spade (Daily Times, February 8, 2014).

As Entman ( 1991) notes that the frames embody in key words, phrases, metaphors, images and visuals; Daily Times frequently using the framing devices like ' talks with murderers', ‘ Taliban as murderers', ‘ our ally US', ' drones as precise machines', ‘ drones as blow to terrorists, and ' peace with murderers' depicting the Taliban in highly negative ways and portraying the US drones as an effective strategy against the militants. When Pakistan launched its own drones, the newspaper did not asserted to stop the US drones, rather it termed the indigenous drones as an added edge in the ' fight against terrorism' (Sept 09, 2015) as has been done by the US drones 'to rid Pakistan of this militant plague' ( September 26, 2013). It frequently opposed the rhetoric of collateral damage by the Pakistani officials and propounded the technological precision of the drones in hitting the right target. As one such editorial piece shows:

It has always been the case that our government representatives have said one thing in front of the public to placate the masses but have always remained silent behind the scenes when it comes to the drone strikes. That is because they themselves know that drones will get the job done they are too scared of doing themselves, done. If applied at right time [drones] can be very effective (Daily Times, Sept 26, 2014).

However, in one editorial comment the Daily Times mentioned the collateral damage and stated that it is potentially boosting rather than undermining terrorists recruitment efforts (Daily Times, May 28, 2016). As the above editorial discourse reveals, Daily Times used to frame the US drone as highly effective in killing the 'bad guys'. It predominantly depicted the US drone in highly positive tone and portrayed the Taliban in highly negatively using the 
emotive language as 'murderers' and their actions as 'murderous'. There is vivid evidence that both the elite newspapers discursively framed the US drone strikes in strikingly different ways. Daily Times excluded the narratives on the sovereignty and collateral damage issue and made the technological precision of the drones more salient. It persistently framed the drones as an effective toll to eliminate the terrorists and underreported the blow effects of the drone attacks that cause the killing of civilian population and fuel resentment against the drones in Pakistan. Thus using the framing process the newspaper made some aspects of the drone issues more salient and downplayed the other aspects by de-emphasizing the collateral damage issue caused by the drone strikes and emphasizing the technological precision of the drones in targeting the militants.

\section{Discussion and Conclusion}

Contrary to the common wisdom that the drones are highly unpopular in Pakistan thus there must exists a negative framing and opposition to the drones across the spectrum of media in Pakistan, the findings reveal a different story. The media framing of the US drones in Pakistani elite press is not homogenous but strikingly differs as the analysis of the editorial discourse reveals. The Express Tribune tends to frame the drones highly negatively, depicting them as a violation of sovereignty thus unacceptable. Daily Times in contrast, framed the drones as an effective strategy to response to the terrorists and terrorism in Pakistan. These findings suggest that when the public opinion is divided on crucial issues as we discussed in the introduction part, the media tend to frame issues in more than one ways and do not necessarily reinforce the official stance. This study raises important questions on the framing of international news. The dominant scholarship on framing of international news suggests that when one actor is under threat from another actor, the news media predominantly accentuate, internalize and align with the dominant political and cultural sentiments. The findings of this study however does not support this prevailing argument and instead content that framing of an international issue with national implications seems to be depended on a number of factors including the fragmented political and public opinion, organizational stances and the effects of the issue at the societal level. We conclude by stating that when it comes to frame an international issue with national implications like the US drones, the news media framing may differ strikingly from one media organization to another and may not necessarily be homogenous. Editorial policy of the news media organizations and the divided public opinion could be factors for the differential framing of US drones in the press of Pakistan. However, this needs further study. Future study could be done in examining the 
framing of the US drones in the vernacular press of Pakistan which has the highest circulation and readership and the TV news framing as the TV media has become a ubiquitous in Pakistani society. Additionally, exploring the militant media in Pakistan would be yet another important project in distilling how the militant press in Pakistan conceptualizes the US drones and the counterterrorism policy. Finally, to expand the media framing scholarship on drones future research could be conducted in exploring the audience framing- how the receivers of these media frames on drones interpret the drone issue. 
Pakistan Journal of Humanities and Social Sciences, 5(2), 2017

\section{References}

Alasuutari, P., Qadir, A., \& Creutz, K. (2013). The domestication of foreign news: stories related to the 2011 Egyptian revolution in British, Finnish and Pakistani newspapers. Media, Culture \& Society, 35 (6), 692- 707.

Bachman, J. (2015). The New York Times and Washington Post: Misleading the public about US drone strikes. Journalism Studies, DOI: 10.1080/1461670X.2015.1073118.

BBC ( 24 May, 2013). http://www.bbc.com/news/world-us-canada-22638533.

Bergen, P. \& Tiedemann, K. (2010). The year of the drone: New York: New American Foundation.

Billig, M. (1995). Banal Nationalism. London: Sage.

Chong, D., \& Druckman, J.N. (2007). Framing theory. Annual Review of Political Science, $10,103-26$.

CNN.Com. (May 18, 2009). U.S. airstrikes in Pakistan called 'very effective'. Retrieved from: http://www.cnn.com/2009/POLITICS/05/18/cia.pakistan.airstrikes/ Accessed on July 4, 2017.

Dawn. (Dec 10, 2013). NA unanimously passes resolution against US drone strikes. Available at: http://www.dawn.com/news/1061704, On Feb 13, 2017.

de Souza, R.( 2010). NGOs in India's elite newspapers: a framing analysis. Asian Journal of Communication, $20 \quad$ (4), 477-493.

Entman, R.M. (1991). Framing US coverage of international news: Contrast in Narratives of the KAL and Iran Air incidents. Journal of Communication, 41 (4), 6-27.

Entman, R.M. (1993). Framing: Toward a clarification of a fractured paradigm. Journal of Communication, 43 (4), 51-57.

Gamson, W. A. \& Modigliani, A. (1989). Gamson, W. A. \& Modigliani, A. (1989). Media discourse on nuclear power: a constructionist approach. The American Journal of Sociology, 95(1), 1-37.

Gitlin, T. (1980). The whole world is watching. Berkeley: University of California Press.

Golan, G. J., \& Carroll, T. R. (2012). The Op-ed as a strategic tool of public diplomacy: Framing the of the 2011 Egyptian revolution . PubliC Relations Review , 630-632.

Golan, G.J., \& Lukito, J. (2015). The rise of the dragon? Framing China's global leadership in the elite American newspapers, The International Communication Gazette, 77(8), 754-772. 
Haider, M. (June 1, 2016). US drone strikes regrettable, must stop: COAS. Available at: http://www.dawn.com/news/1262054, On Feb 5, 2017.

Iyengar, S. (1990). Framing responsibility for political issues: The case of poverty. Political Behavior, 12 (1), 19- 40.

Jones, T.M., Sheets, P., \& Rowling, C.M. ( 2011). Differential news framing of Unammed Aerial Drones: Efficient and efective or illegal an inhumane? .APSA 2011 Anuual Meeting Paper.

Lee, CC, Li, H., \& Lee, Francis.L.F. (2011). Symbolic use of decisive events: Tiananmen as a news icon in the editorials of the elite US press. International Journal of Press /Politics, 16 (3), 335-356.

Lee, Francis L.F., \& Lin, Angel M.Y. (2006). Newspaper editorial discourse and the politics of the self-censorship in Hong Kong, Discourse \& Society, 17 (3), 331-58.

$\mathrm{Li}$, Juan. 2009. Intersexuality and national identity: discourse of national conflicts in daily newspapers in the United States and China. Discourse \& Society, 20 (1), 85-121.

Nadadur, R.D. (2007). Self- censorship in the Pakistani print media. South Asian Survey, 14 (1), 45-63.

Neuman, W.R., Just, M.R., Crigler, A.N. (1992). Common Knoeledge. Chicago: University of Chicago Press.

New York Times. ( Nov 3, 2008). Petraues in Pakistan Hears Complaints About Missile Strikes. Available at: http://www.nytimes.com/2008/11/04/world/asia/04pstan.html.

Norris, P. (1995). The restless searchlight: Networks news framing of the post-Cold War world. Political Communication, 12 (4), 357-370.

Ottosen, R. (2014).Underreporting the Legal Aspects of Drone Strikes in International Conflicts: A Case Study of How Aftenposten and The New York Times Cover Drone Strikes. Conflict and Communication Online 13 (2): 1-12.

Pew Research Centre. (June 29, 2012). Little Support in Pakistan for American Drone Strikes Targeting Extremist Leaders. http://www.pewresearch.org/daily-number/littlesupport-in-pakistan-for-american-drone-strikes- targeting-extremist-leaders/, Accessed on, Jan 20, 2017.

Pew Research Centre. (May 28, 2015). Public continues to Back U.S. drone attacks.http://www.people-press.org/2015/05/28/public-continues-to-back-u-s-droneattacks/, On Feb 2, 2017. 
Pakistan Journal of Humanities and Social Sciences, 5(2), 2017

Qadir, A. \& Alasuutari, P. ( 2013). Taming terror: domestication of the war on terror in the Pakistan media. Asian Journal of Communication, 23 (6), 575-589.

Rasul, A., Robinson, B.C, \& McDowell, S.D. (2015). The Taliban factor: conflict in Afghanistan and elite South Asian newspapers. The Journal of International Communication, 22 (2), 273-292.

Reese, S.D., \& Lewis, S.C. (2009) . Framing the War on Terror: the internalization of policy in the US press. Journalism, 10 (6), 777-797.

Romero-Trillo, J. (2011). The representation of liminality conflicts in the media. Journal of Multicultural Discourse, 6 (2), 143-158.

Semetko, H.A., \& Valkenburg, M.P. ( 2000). Framing European politics: A content analysis of press and television news. Journal of Communication, 50 (2), 93-109.

Shah, A. (May 22, 2016). Why drone blowback in Pakistan is a myth. Dawn, Available at: http://www.dawn.com/news/1259933, On Feb, 11, 2017.

Sheets, P., Rowling, C., \& Jones, T.M. (2015). The view from above (and below): A comparison of American, British, and Arab news coverage of US drones. Media, War \& Conflict, 8 (3), 289-311.

Shoemaker, P., \& Reese, S. (1996). Mediating the message: Theories of influences on media content. White Plains: Longman.

Stories, L.K., Madden S.L., \& Liu, B.F. (2014). The death of bin Laden: How Russia and US media frame counterterrorism. Public Relations Review, 40 (3), 429-439.

Strauss,A., \& Corbin, J. (1990). Basics of qualitative research: Grounded theory procedures and techniques. London: Sage.

Taj, F. (2010). The year of the drone misinformation. Small Wars \& Insurgencies, 21 (3), 529-535.

The Guardian (2013). Drone strikes by US may violate international law, says UN. Available at: https://www.theguardian.com/world/2013/oct/18/drone-strikes-us-violate-law-un, accessed on 12-8-2017.

Williams, B.G. (2010). The CIA's Covert Predator Drone War in Pakistan, 2004- 2010: The History of an Assassination Campaign. Studies in Conflict \& Terrorism, 33 (10), 871-892.

Wodak, R, de Ceillia, R., Reisigl, M., \& Liebhart, K. (2009). The Discursive Construction of National Identities. Edinburg: Edinburg University Press. 